\title{
Transferring performativity from speech to writing: illocutionary acts and incantation bowls ${ }^{1}$
}

\author{
Daniel James Waller \\ Rijksuniversiteit Groningen \\ d.j.waller@rug.nl
}

\begin{abstract}
This article considers the interface between orality and textuality in the Aramaic incantation bowls, as well as the use of performative utterances in the texts of their spells. It demonstrates that writing and writtenness were central to bowl praxis as a whole, and argues that the bowls reflect a growing understanding of writing as performative in itself. In light of this, it suggests that the use of illocutionary acts in the bowl texts reflects the (gradual and ongoing) transfer of performativity from speech to writing in Sasanian Mesopotamia. Such acts of "word magic" in the bowls as oaths and curses are more likely to represent transitional language or a kind of "oral residue" than the verbatim representation of speech or spoken acts.

Keywords: Aramaic incantation bowls, Illocution, Written performatives, Orality, Textuality, Material studies
\end{abstract}

\section{Introduction}

In this brief contribution, I consider two aspects of the late antique Aramaic incantation bowls: their use of both implicit and explicit illocutionary acts, and the complicated relations that their written spells instantiate between orality and textuality. The texts of the incantation bowls were inscribed upon domestic surfaces (simple Sasanian household ware, the kind used for food) and represent the striking deployment of writing within domestic spaces. Designed to protect the owners of the bowls from demons and other malevolent forces, the bowls were buried upside-down beneath the floors of people's homes. ${ }^{2}$ Once interred, their continuing efficacy as apotropaia was presumably guaranteed by the stability and permanence of the written word. Charles Häberl (2015) has recently argued from the use of performative utterances in the bowl texts that an oral ceremony lay behind the production of the bowls, and that the writing of the bowls was thus of secondary importance. Pace Häberl, this contribution argues that writing and writtenness were central to bowl praxis as a whole. Illocution is simply a feature of language-in-use (whether spoken or written) and I suggest that the bowls represent a move towards a popular or vernacular conception

1 I would like to thank Mladen Popović, as well as this article's anonymous referees for their comments and bibliographic suggestions.

2 On bowl praxis, see, e.g., Montgomery 1913: 40-101; Naveh and Shaked 1985: 13-9; Frankfurter 2015. For two synthetic summaries of bowl scholarship, see Bohak 2008: 183-93 and Harari 2017: 133-40, 234-51. 
of writing as a performative act. ${ }^{3}$ Even though the texts of the bowls could not have been read (in the normal sense of the word) by the bowls' presumably illiterate owners, ${ }^{4}$ I argue that bowl praxis shows a growing understanding of writing as performative in itself, and that the use of illocutionary utterances in the bowls reflect the (gradual and ongoing) transfer of performativity from speech to writing in Sasanian Mesopotamia. I argue that these illocutionary acts - especially such acts of "word magic" in the bowls as oaths and curses - are more likely to represent "transitional" language or a kind of "oral residue" than the verbatim representation of speech or spoken acts.

\section{Background}

Composed during the late Sasanian and early Islamic period and inscribed upon unglazed earthenware bowls in several contemporary dialects of Aramaic, ${ }^{5}$ the Aramaic incantation bowls are located right at the interface between orality and textuality. ${ }^{6}$ As written media, many of their texts demonstrate the persistence of oral compositional processes, as well as the significant role played by memory in their production. ${ }^{7}$ Many bowls also include (figurative) artwork and geometric designs, ${ }^{8}$ and we further encounter a variety of different

3 The study of the illocutionary power of language was inaugurated by Austin (1962) and Searle $(1969 ; 1979)$. Tambiah $(1968)$ provided speech act theory with its most influential stamp in relation to magic. On the transfer of performativity from speech to writing, see Danet (1997). On the active and performative role of writing, see, e.g. Fraenkel (2006; 2007).

4 On visual literacy, as well as ways of reading without being able to read, see, e.g. Bonfiglio (2017) and Waller (2019). The latter explores the diverse material form(s) of text in the bowls as a kind of communication in themselves. Writing is typically viewed from the perspective of speech, but it can also express meaning through visual, spatial, and aesthetic determinations, such as letter-form, position, or the arrangement of text. For example, the maze-like spirals and concentric circles of the bowl texts (wherein demons may have become confused and trapped) convey an easily legible visual message that both evokes and supports the verbal message of the bowl texts. For several recent treatments of "text as art" across different periods, see, e.g., Bedos-Rezak and Hamburger 2016; Kiilerich 2011; Leatherbury 2019; Rhoby 2017; Thunø 2011.

5 Jewish Babylonian Aramaic (JBA), Mandaic, and Syriac. Approximately two-thirds of the corpus of known incantation bowls were inscribed in JBA. A handful of bowls were also inscribed in Pahlavi and Arabic.

6 For recent work on the interactions between orality and textuality, see, e.g., Weissenrieder and Coote 2015; Rubanovich 2015; Lardinois et al. 2011.

7 Several clues favour the oral transmission and memorial reproduction of spell formulae in the bowls. Foremost among these are the many parallel and/or duplicate formulae that we encounter across the bowl corpus. Produced by different magical practitioners in different geographical locations, these duplicates demonstrate variations in formulae that betray little evidence of reproduction from written Vorlagen; they also reveal how free bowl practitioners were to combine and creatively rearrange different formulae and textual units. The corrupt citation and plene spelling of Biblical verses in the JBA bowls also demonstrate the reproduction of formulae from memory and not written texts. Some duplicate bowls, however, bear the same magical signs, which would have been difficult to reproduce without a visual model. For a more extensive treatment of these issues, see Bohak (2008: 185-7) and the literature cited therein. On the Bible in the bowls, see Lanfer 2015.

8 See Vilozny (2017) for an extensive treatment of the drawings in the bowls. 
inscriptional practices and manipulations of graphic signs across the corpus as a whole. ${ }^{9}$ The bowls thus reflect various interdependencies of oral-scribal dynamics, as well as countless combinatory possibilities of text and image. ${ }^{10}$ These complex oral, textual, visual, and memorial interactions suggest a fluid social and semantic environment where media interfaces, transits, and tensions were the rule.

\section{Writing, writtenness, and written performatives}

Scholarship in recent decades has challenged the so-called great divide between orality and textuality, speech and writing. It has shown that, despite its brute explicative potential, the articulative power of this divide is inherently limited. Further evidence that the utility of this model has passed is to be found in a complex recent study of the incantation bowls by Charles Häberl (2015). Häberl's study analyses the illocutionary act in the incantation bowls, and adduces the use of both implicit and explicit performatives in the bowls to suggest that the bowl texts were actually transcriptions of ritual utterances that represent the direct speech of the magical practitioner. ${ }^{11}$ Häberl hypothesizes a ritual situation (including whispered incantations, the construction of a magical circle, and the inscription and burial of the bowl) where the text written on the bowl was simultaneously spoken out loud and transcribed before an audience. This hypothesis represents the first coherent attempt to theorize both the (re)production of spell formulae and the ritual processes that may have accompanied the production of the bowls. It also emphasizes to great effect the illocutionary nature of many bowl formulae. However, Häberl's focus on performativity and the oral transmission of bowl formulae leads him to conclude that the writing of the incantation bowls, "which was a reflection of the oral composition ... was quite possibly of secondary importance" (p. 396). In what follows, I will argue that the bowl formulae were not "primarily oral compositions" that just "happened to be written down" (Häberl 2015: 369), but that writing and writtenness were key to beliefs about the efficacy of the bowls as apotropaic objects.

Despite the role of oral and memorial processes in the transmission and composition of bowl formulae, the bowls as inscribed media reflect the centrality of writing to bowl praxis. Stability and continuity inheres in the visual trace, and writing has the power to make visible and enduring what is otherwise fleeting and ephemeral (namely, the spoken word). Inscription grants a kind of

9 These range from invented signs and ostentatious displays of non-writing to pseudo- or imitation scripts that closely resemble the forms of known alphabets.

10 On the different patterns and arrangements of text in the bowls, see Morony 2003: 84, 90-94.

11 Because we possess no contemporary Sasanian manuals or magical recipe books, we cannot know with certainty whether the bowls were recited either during or after their inscription. Shaked (1997: 104) has suggested that they were not. He points in this regard to the bowls written in invented or pseudo-scripts (which are commonly attributed to illiterate charlatans), though he does note that - having gone to the trouble of faking a text an illiterate practitioner would presumably have had the wherewithal to provide an adequate "recitation" of the "text" in order to satisfy any expectations his client may have had in this regard. 
permanence (and materiality) to ritual elements, ${ }^{12}$ and this aspect of permanency is key to bowl praxis. From the inscription and burial of the bowls to the apotropaic and exorcistic goals reflected in their texts, the bowls plainly reflect a concern that constant communication and communion be achieved with their transmundane interlocutors. Once inscribed, the bowl as a written object was clearly intended to function as an autonomous communication that could be maintained independent of the magical practitioner in the client's home. Further overwhelming evidence for the centrality of writing to bowl praxis is also to be found in the so-called 'pseudo-script' bowls, which instantiate a variety of inscriptional practices and manipulations of graphic signs. ${ }^{13}$ These range from invented signs and ostentatious displays of non-writing to imitation scripts that closely resemble the forms of known alphabets. (See Figures 1 and 2, which show two bowls produced by the same bowl practitioner. Though inscribed with a series of invented signs, these bowls nevertheless reflect an elaborate repertoire of repeated and sometimes quite intricate signs.) Such "texts" may represent many things, from the work of illiterate charlatans to deliberate attempts to strip written language of all semiotic convention and instantiate a writing system better suited to communications with angels and demons. ${ }^{14}$ The value and purpose attributed to the pseudo-script bowls (especially in light of the variety of

12 Fritz Graf (2015) has recently argued from the existence of so many inscribed media in ancient magic that, in addition to things said and things done in ancient ritual, we make more room in our scholarly analyses for things written. Focusing on Graeco-Roman magic, Graf highlights the variety of potent inscriptional practices in magical texts: charaktêres; letter combinations with no reference to spoken language; written materials meant for eating or drinking; and drawn images and texts.

13 These "pseudo-script" bowls are commonly attributed to illiterate magical practitioners who passed them off onto non-literate clients. Häberl offers a different explanation for these bowls, which has the advantage of sparing them from relegation to the netherworld of charlatanism. In light of the ritual situation that he hypothesizes, Häberl notes both the difficulties inherent in inscribing the interior of a bowl and the fact that writing is typically about one-tenth the speed of speech. He then suggests that "some magicians may have merely mimicked the act of writing during the course of the ritual [that he outlines], thereby producing the so-called "pseudo-script texts". We therefore need not dismiss their creators as charlatans, as they would also need to be completely versed in the other components of the ritual in order to satisfy their clients" (2015: 396). The case of the pseudo-script bowls, however, is far more complicated than either appeals to charlatanism or Häberl's theory would indicate. See Waller 2019, which shows that meticulous attention was paid to the inscription of many pseudo-script bowls, and that many other bowls inscribed with pseudo-scripts betray both great inventiveness and different mechanical aspects of sign formation that would have slowed down inscription. Because these bowls do not indicate haste, but instead reveal both forethought and a deliberative mode of inscription, they do not seem to confirm the kind of ritual situation that Häberl outlines. The bowls were produced by many different practitioners in many different locations for many different people, and we cannot take a one-size fits all approach to their inscriptions. Many "pseudo-script" bowls were undoubtedly produced by charlatans; others were perhaps produced according to the ritual situation that Häberl hypothesizes; yet others may reflect different goals and different beliefs about writing (see note 14 below).

14 Some of these bowls clearly reflect the conscious development of highly stylized (nonglottographic) repertoires of signs. The ways in which these bowls dismantle and reconstruct written forms tap into the materiality and plasticity of writing in order to better control it. Many of the so-called pseudo-script bowls may thus reflect a kind of inscribed 


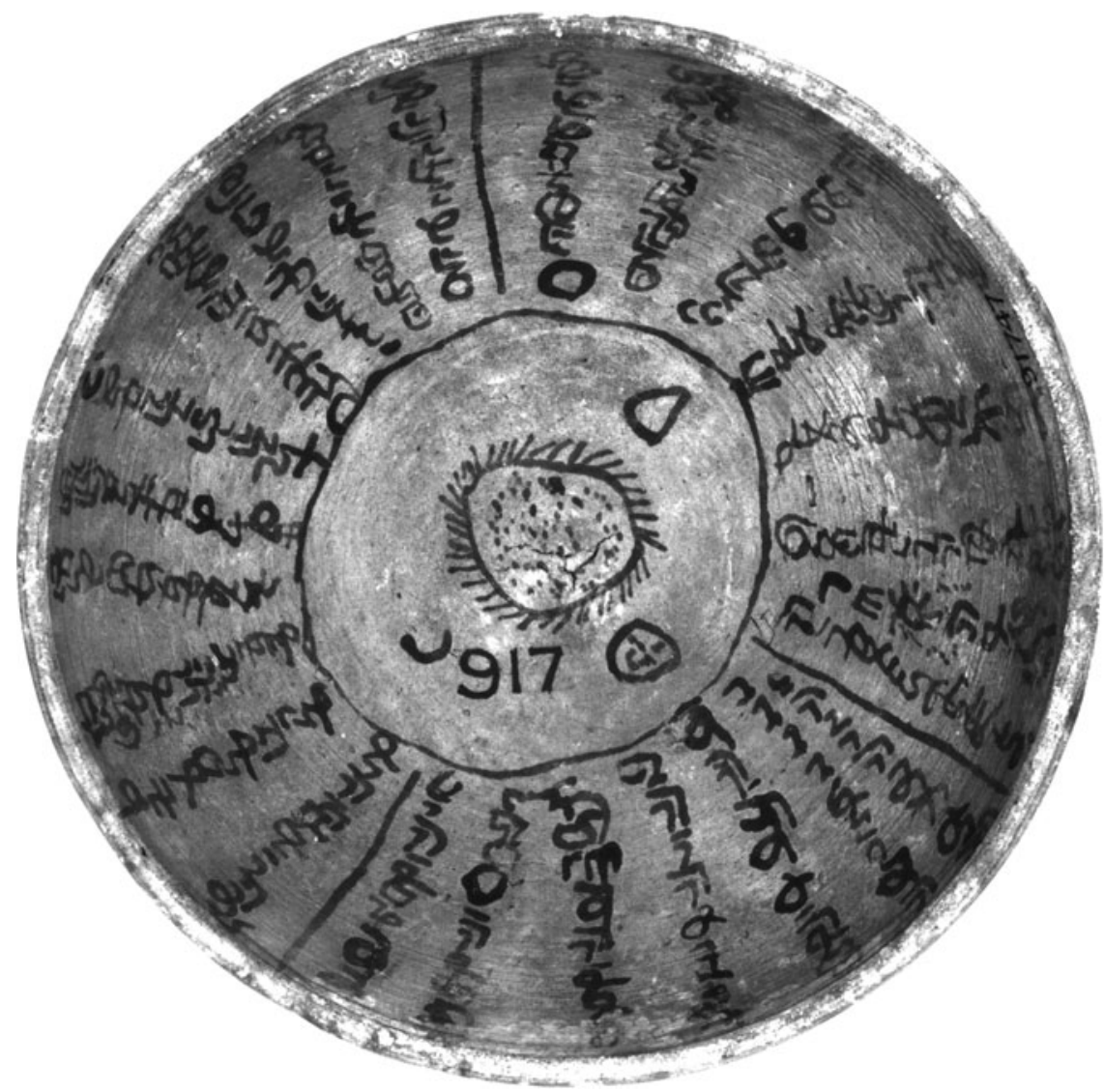

Figure 1. BM 91747. One of several bowls inscribed by the same hand. The inscription consists of an invented script which reflects a fairly developed repertoire of repeated and sometimes quite intricate signs. (C) The Trustees of the British Museum

graphic behaviours they instantiate) undoubtedly varied from practitioner to practitioner and client to client. But regardless of how individual pseudo-script bowls were perceived, their authority was plainly derived from the status of writing and the prestige of true literacy elsewhere in society. ${ }^{15}$ Bowl praxis emerged against a common Near Eastern background where writing and script played a generative role in shaping conceptions about the power of words, ${ }^{16}$ and the

glossolalia (or glossographia) - writing systems intentionally designed to represent linguae ignotae or sacrae.

15 See Gordon (2014: 253-4) and the literature cited therein. See also Balke and Tsouparopoulou (2016), which focuses on the material and "power-discursive" character of inscribed artefacts in ancient Mesopotamia.

16 The Egyptians, for example, referred to the hieroglyphic script as "the words of the gods" $(m d w n \underline{t r})$, while "Egyptian letters were the chief technology of a hierocratic scribal elite 


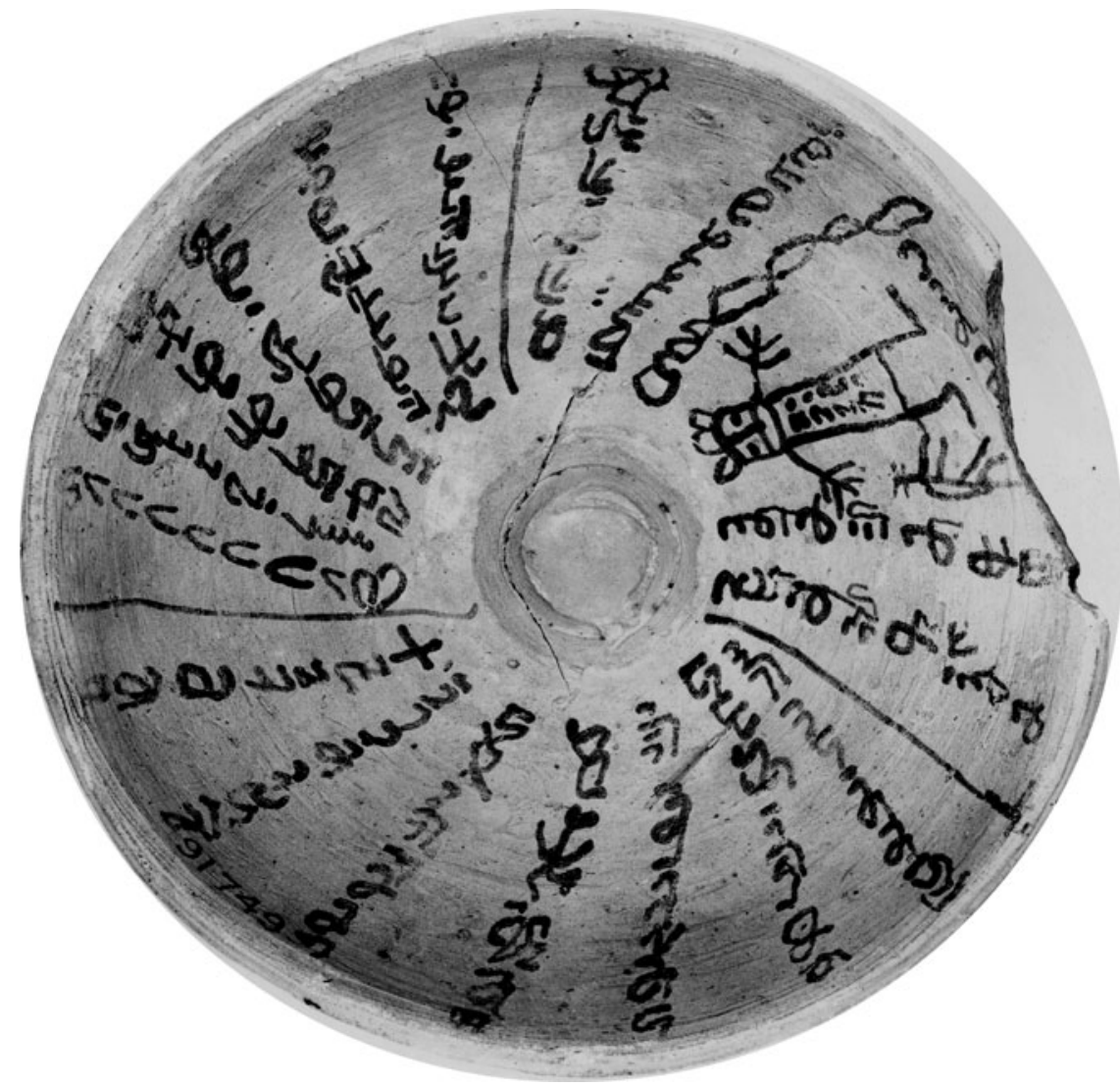

Figure 2. BM 91749. One of several bowls inscribed by the same hand. The inscription consists of an invented script which reflects a fairly developed repertoire of repeated and sometimes quite intricate signs. (C) The Trustees of the British Museum

bowls reflect the development of an extensive magical practice built on the instrumentalization of writing. ${ }^{17}$ They reflect a wider surge in the use of writing (in particular as a technology for communicating with transmundane powers)

who preserved and enacted rituals - and by extension the cosmic order itself - through the written word" (Frankfurter 1994: 192). With reference to Mesopotamia, various statements by scribal elites reveal a conception of writing as "the cosmic bond of everything" (markas kullat). See Noegel (2010) and the literature cited therein. Writing and script did not just play a role in shaping conceptions of the sign, but also in shaping the self and one's group or ethnic identity. On the correlations between script and religious identity in the incantation bowls, see Harviainen (1993: 32, 36; 1995).

17 On the scribalization of Jewish magic in the third to fourth centuries CE, see Bohak 2008: 281-5. Bohak also queries "whether the sudden appearance of the custom of writing [the incantation] bowls is not the result of a mere change of scribal medium, that is, whether texts such as are inscribed on the bowls had earlier been inscribed on perishable materials, or even applied in an oral fashion, and therefore vanished from the archeological record" (Bohak 2008: 189). 
across the ancient world, ${ }^{18}$ and it is against this background that I suggest we read the illocutionary act in the incantation bowls as reflective of the transfer of performativity from speech to writing.

The transfer of performativity from speech to writing is common in periods when writing is becoming institutionalized. ${ }^{19}$ The Sasanian period in particular may be characterized by a spreading awareness of the contrast between oral and written traditions, as well as a widespread reliance in Babylonia and the Middle East on written documents (Shaked et al. 2013: 3-7). People made constant use of writing, from deeds of sale to deeds of divorce. ${ }^{20}$ The bowls may thus be characterized as "product[s] of an environment steeped in literacy" (Häberl 2015: 369). ${ }^{21}$ As written objects, the bowls were also embedded in an environment populated by human and transmundane agents engaged in complex social interactions. ${ }^{22}$ The inscription, inversion, and interment of the bowls transformed them into agents of measurable power within this environment. As objects imbued with "social agency", the bowls worked to constitute new social relationships between their owners and the demons that troubled them. ${ }^{23}$ In speech act terms, the bowl texts were acts of writing that effected a change in the world, ${ }^{24}$ that compelled demons (the cause of various illnesses and other woes in the bowl texts) to desist from their activities and/or adjust their behaviours in relation to the owners of the bowls.

Writing acts. It can make things happen, and the writing (as well as overturning and burying) of the bowls represented a performative act. Performativity is simply a feature of language-in-use - whether spoken or written - which may be expressed in constitutive ritual events, and I suggest that the bowls reflect a growing view of writing as constitutive of social action, rather than a view of writing as a verbatim record of speech or oral actions. If we take utterance as

18 See, e.g., Faraone 2018.

19 See, e.g., Danet and Bogoch (1992a; 1992b) on the transitional language in Anglo-Saxon legal documents, or Kittay (1988) and Kittay and Godzich (1987) on transitional literary texts from medieval France. There are important parallels between the development of literacy and the institutionalization of writing in the ancient world and the supersession of oral culture by literate practices in the mediaeval period (Stock 1987: 32-4). On writing and performativity in the ancient world, see, e.g., Mandell 2012: 150-53.

20 Indeed, both the get (or Jewish deed of divorce) and the ketubba (or Jewish marriage contract) represent legal situations where written documents were mandatory almost from Biblical times in Jewish law. As Danet notes, "almost from the beginning of the history of writing in ancient times, legal documents contain evidence of a latent struggle to transfer performativity from speech to writing" (1997: 15).

21 Shaked clarifies this characterization by noting that, even if we distinguish the Sasanian period as "a period of high literacy, it does not mean, of course, that literacy was a skill that most people possessed" (2015: 43).

22 Demons were everywhere. The bowls are ample testament to this, but note also the following passage from bt Ber 6a: "It has been taught: Abba Benjamin says, If the eye had the power to see them, no creature could endure the demons. Abaye says: They are more numerous than we are and they surround us like the ridge around a field. R. Huna says: Every one of us has a thousand on his left side and ten thousand on his right side."

23 On the role of "object agency" in ritual practice, a reflection of the so-called New Materialism, see, e.g., Boschung and Bremmer 2015.

24 See Fraenkel $(2006 ; 2007)$ who examines "acts of writing" in the same way as Austin analysed speech acts. 
a neutral term, a verbal sequence irrespective of written or spoken medium, we can better appreciate the existence of written documents that contain utterances which are not to be read or interpreted as speech (Kittay 1988). To read them as deriving their authority from speech is to misread them. Written texts are material phenomena, and because writing renders utterances permanent, it originates a class of utterances that should be understood primarily in terms of their writtenness (even if these utterances were transmitted orally and reproduced from mental templates). ${ }^{25}$ The change in the world that the bowl texts were designed to bring about was guaranteed by their permanence in writing. Writing is what constituted the bowls as both autonomous communications and autonomous apotropaic objects. In many literate and pre-literate societies, both spoken and written constitutive acts are treated as (legally) binding, and it is the writtenness of the language in the bowls that presumably rendered their oaths, adjurations, curses, and other legal formulae both permanent and indissoluble. ${ }^{26}$ In short, the bowl texts represent the popular investment of authority in written documents and reflect a growing view of writing in itself as constitutive of action. ${ }^{27}$ An excellent example of this, and evidence of the growing popular deployment of writing's performative potential, is the adaptation of the get to bowl praxis. ${ }^{28}$ The use of such legal formulae, as well as the deployment of oaths, curses and other types of "oral residue" in the bowls, was undoubtedly a means to enhance the performative potential of these objects as autonomous communicative acts. I suggest that the bowl - the material support for the inscription - also added to the felicity of these constitutive acts. As simple Sasanian kitchenware, the finished bowl both derived from and slotted back into the gestural world of the household. As Frankfurter (2015) points out, the inscribed bowl simultaneously calls attention to its origin in day-to-day domestic life and to its transformation into a site of exorcistic power. The performativity of the bowls was thus intimately related not just to the materiality of their inscription, but to the materiality of the bowl itself (as more than just a writing surface).

\section{Conclusion}

In concluding, I note that the incantation bowls are a genre of magical texts that emerged from and were shaped by - and shaped in return - the interface between seeing, reading, and speaking. They reveal the rapidly developing scribality of

25 On the agency of writing and the value of treating inscriptions as intentionally designed artefacts within diverse spatial contexts - rather than finished texts whose meaning lies almost exclusively in their wording - see the contributions in Berti et al. (2017), which treat these issues on the basis of evidence from Greek and Roman antiquity through to the Middle Ages.

26 On legal formulae in the bowls, see Manekin Bamberger 2015.

27 On the diffusion of literacy from scribal circles into the laity, see, e.g., Bar-Ilan 2014.

28 James Montgomery referred to the use of the get in the bowls as a "happy thought of the magicians" whereby "the powers of binding and loosing claimed by the rabbis" were applied to the "unions of demons and mortals" (1913: 158-9). Variations on divorce formulae are common in the bowls. On the use of the get in the bowls, see Shaked 1999, Frim 2015, and Levene 2003. On the theme of humans marrying and divorcing demons, see Folmer 2016. 
late antique magic, as well as the mainstreaming of writing within domestic spaces. This brief contribution has noted the oral transmission of bowl formulae, and the persistence of oral and memorial compositional structures in the written texts of the bowls. It has attempted further to complicate our characterization of such processes within the bowls. We can only speculate about the potential recitation of the bowl texts, and I have suggested that the performative act in the bowls was inherent to the written object itself, rather than any potential oral ceremony. In fact, the bowls appear to represent a popular experiment with the performative potential of writing, while some of the pseudo-script bowls may even represent the work of "laymen, who affected to write their own prescriptions" (Montgomery 1913: 28).

Given the heterogeneous social contexts of the bowls, however, no argument should be taken to apply to the corpus as a whole; the value and function attributed to the bowls undoubtedly varied. Nonetheless, the weight of concrete evidence shows that while many bowl formulae were undoubtedly transmitted orally and reproduced from mental templates, the texts of the bowls were not so much organized in conformity with the phenomenology of sound but of sight. Writing is a visual media, and the texts and pseudo-texts of the bowls were patterned and encoded according to diverse visual strategies, from hectic spirals to radial registers and concentric circles. Writing is also a way of extending cognition into the environment, and the unusual inscriptional practices in the bowls open up a cognitive space in the perception of the structure of writing where transmundane or counter-intuitive beings are themselves made more "legible" (such that the bowls may even have been "read" by their (presumably) illiterate owners, even as the bowls' demonic interlocutors were bamboozled by and trapped within the spiralling maze of their texts). Conditioned in depth by chirographic proclivities, inscribed upon cheap domestic surfaces, and deployed within domestic spaces, the bowls reflect the popular institutionalization of writing in Sasanian Mesopotamia. As a visual and material means of communication and mediation, they demonstrate the power of writing and the rhetorical reach of writtenness, and suggest the transfer of performative or constitutive acts from speech to writing.

\section{Bibliography}

Austin, John L. 1962. How to Do Things with Words: The William James Lectures Delivered at Harvard University in 1955. Cambridge, MA: Harvard University Press.

Balke, Thomas E. and Christina Tsouparopoulou. 2016. Materiality of Writing in Early Mesopotamia. Berlin: de Gruyter.

Bar-Ilan, Meir. 2014. "Socialized literacy in antiquity", Maarav 21/1-2, 237-50.

Bedos-Rezak, Brigitte Miriam and Jeffrey F. Hamburger. 2016. Sign and Design: Script as Image in Cross-Cultural Perspective (300-1600 CE). Washington, DC: Dumbarton Oaks Research Library and Collection.

Berti, Irene, Katharina Bolle, Fanny Opdenhoff, and Fabian Stroth. 2017. Writing Matters: Presenting and Perceiving Monumental Inscriptions in Antiquity and the Middle Ages. Berlin: de Gruyter.

Bohak, Gideon. 2008. Ancient Jewish Magic: A History. Cambridge: Cambridge University Press. 
Bonfiglio, Ryan P. 2017. "Visualizing literacy: images, media, and method", Biblical Interpretation 25, 293-319.

Boschung, Dietrich and Jan N. Bremmer. 2015. The Materiality of Magic. (Morphomata Volume 20.) Paderborn: Wilhelm Fink.

Danet, Brenda. 1997. "Speech, writing and performativity: an evolutionary view of the history of constitutive ritual", in Britt-Louise Gunnarsson, Per Linell, and Bengt Nordberg (eds), The Construction of Professional Discourse. London: Longman, 13-41.

Danet, Brenda and Bryna Bogoch. 1992a. "From oral ceremony to written document: the transitional language of Anglo-Saxon wills", Language \& Communication 12/2, 95-122.

Danet, Brenda and Bryna Bogoch. 1992b. "Whoever alters this, may God turn his face from him on the day of judgment': curses in Anglo-Saxon legal documents", The Journal of American Folklore 105/416, 132-65.

Faraone, Christopher A. 2018. The Transformation of Greek Amulets in Roman Imperial Times. Philadelphia: University of Pennsylvania Press.

Folmer, Margaretha. 2016. "On marrying and divorcing a demon: marriage and divorce themes in the Jewish, Christian, and pagan world", in Alberdina Houtman, Tamar Kadari, Marcel Poorthuis, and Vered Tohar (eds), Religious Stories in Transformation: Conflict, Revision and Reception. Leiden: Brill, 275-99.

Fraenkel, Béatrice. 2006. "Actes écrits, actes oraux: la performativité à l'épreuve de l'écriture", Études de communication 29/1, 69-93.

Fraenkel, Béatrice. 2007. “Actes d'écriture: quand écrire c'est faire”, Langage et société 121-2, pp. 101-12.

Frim, Daniel J. 2015. “'And it was in the dwelling of Rabbi Joshua bar Perahiah': notes on the anti-demonic get in the Jewish Babylonian Aramaic incantation bowls", The Review of Rabbinic Judaism 18, 192-226.

Frankfurter, David. 1994. "The magic of writing and the writing of magic: the power of the word in Egyptian and Greek traditions", Helios 23/2, 189-221.

Frankfurter, David. 2015. "Scorpion/Demon: on the origin of the Mesopotamian apotropaic bowl", Journal of Near Eastern Studies 74/1, 9-18.

Gordon, Richard. 2014. "Charaktêres between antiquity and renaissance: transmission and re-invention", in V. Dasen and J.-M Spieser (eds), Les savoirs magiques et leur transmission de l'Antiquité à la Renaissance. Florence: SISMEL/Edizioni del Galluzzo, 253-300.

Graf, Fritz. 2015. "Magie et écriture: quelques réflexions", in Magali de Haro Sanchez (ed.), Écrire la magie dans l'antiquité: Actes du colloque international (Liège, 13-15 octobre 2011). Liège: Presses Universitaires de Liège, 227-37.

Häberl, Charles G. 2015. "Aramaic incantation texts between orality and textuality", in Julia Rubanovich (ed.), Orality and Textuality in the Iranian World: Patterns of Interaction across the Centuries. Leiden: Brill, 365-99.

Harari, Yuval. 2017. Jewish Magic before the Rise of Kabbalah. Detroit: Wayne State University Press.

Harviainen, Tapani. 1993. "Syncretistic and confessional features in Mesopotamian incantation bowls", in L'Ancien Proche-Orient et les Indes: parallélismes interculturels religieux. Helsinki: Finnish Oriental Society, 29-37.

Harviainen, Tapani. 1995. "Pagan incantations in Aramaic magic bowls", in Markham J. Geller, Jonas C. Greenfield, and M.P. Weitzman (eds), Studia Aramaica: New Sources and New Approaches. Oxford: Oxford University Press, 53-60.

Kiilerich, Bente. 2011. "Visual and functional aspects of inscriptions in early church floors", Acta ad Archaeologiam et Artium Historiam Pertinentia 24, 45-63. 
Kittay, J. 1988. "Utterance unmoored: the changing interpretation of the act of writing in the European middle ages", Language in Society 17, 209-30.

Kittay, J. and W. Godzich. 1987. The Emergence of Prose: An Essay in Prosaics. Minneapolis: University of Minnesota Press.

Lanfer, Peter T. 2015. "Why Biblical scholars should study Aramaic bowl spells", Aramaic Studies 13, 9-23.

Lardinois, André, Josine Blok, and M.G.M. van der Poel. 2011. Sacred Words: Orality, Literacy and Religion. Leiden: Brill.

Leatherbury, Sean V. 2019. Inscribing Faith in Late Antiquity: Between Reading and Seeing. London and New York: Routledge.

Levene, Dan. 2003. "AA happy thought of the magicians', the magical get", in Robert Deutsch (ed.), Shlomo: Studies in Epigraphy, Iconography, History and Archaeology in Honor of Shlomo Moussaief. Tel Aviv: Archaeological Center Publications, pp. 175-84.

Mandell, Alice. 2012. "II bless you to YHWH and His Asherah' - writing and performativity at Kuntillet 'Ajrud", Maarav 19/1-2, 131-62.

Manekin Bamberger, Avigail. 2015. "Jewish legal formulae in the Aramaic incantation bowls", Aramaic Studies 13, 69-81.

Montgomery, James Alan. 1913. Aramaic Incantation Texts from Nippur. Philadelphia: University of Pennsylvania Press.

Morony, Michael G. 2003. "Magic and society in late Sasanian Iraq", in Scott Noegel, Joel Walker, and Brannon Wheeler (eds), Prayer, Magic, and the Stars in the Ancient and Late Antique World. University Park, PA: Pennsylvania State University Press, 83-107.

Naveh, Joseph and Shaul Shaked. 1985. Amulets and Magic Bowls: Aramaic Incantation of Late Antiquity. Jerusalem: Magnes Press.

Noegel, Scott B. 2010. “'Sign, sign, everywhere a sign': script, power, and interpretation in the ancient Near East", in Amar Annus (ed.), Divination and Interpretation of Signs in the Ancient World. Chicago: The Oriental Institute of the University of Chicago, 143-62.

Rhoby, Andreas. 2017. "Text as art? Byzantine inscriptions and their display", in Irene Berti, Katharina Bolle, Fanny Opdenhoff, and Fabian Stroth (eds), Writing Matters: Presenting and Perceiving Monumental Inscriptions in Antiquity and the Middle Ages. Berlin: de Gruyter, 265-83.

Rubanovich, Julia. 2015. Orality and Textuality in the Iranian World: Patterns of Interaction across the Centuries. Leiden: Brill.

Searle, John. 1969. Speech Acts: An Essay in the Philosophy of Language. Cambridge: Cambridge University Press.

Searle, John. 1979. Expression and Meaning. Cambridge: Cambridge University Press.

Shaked, Shaul. 1997. "Popular religion in Sasanian Babylonia", Jerusalem Studies in Arabic and Islam 21, 103-17.

Shaked, Shaul. 1999. "The poetics of spells: language and structure in Aramaic incantations of late antiquity: 1. The divorce formula and its ramifications", in Tzvi Abusch and Karel van der Toorn (eds), Mesopotamian Magic: Textual, Historical, and Interpretative Perspectives. Groningen: Styx Publications, 173-95.

Shaked, Shaul. 2015. "Orality and esotericism: reflections on modes of transmission in late antiquity", in Julia Rubanovich (ed.), Orality and Textuality in the Iranian World: Patterns of Interaction across the Centuries. Leiden: Brill, 43-62.

Shaked, Shaul, James Nathan Ford, and Siam Bhayro. 2013. Aramaic Bowl Spells: Jewish Babylonian Aramaic Bowls. Leiden: Brill 
Stock, Brian. 1987. The Implications of Literacy: Written Language and Models of Interpretation in the 11th and 12th Centuries. Princeton: Princeton University Press.

Tambiah, Stanley J. 1968. "The magical power of words", Man 3, 175-208.

Thunø, Erik. 2011. "Inscription and divine presence. Golden letters in the early medieval apse mosaic", Word \& Image 27, 279-91.

Vilozny, Naama. 2017. Lilith's Hair and Ashmedai's Horns: Figure and Image in Magic and Popular Art: Between Babylonia and Palestine in Late Antiquity. Jerusalem: Yad Izhak Ben-Zvi. (Hebrew.)

Waller, Daniel James. 2019. "Curious characters, invented scripts, and ... charlatans? 'Pseudo-Scripts' in the Mesopotamian magic bowls", Journal of Near Eastern Studies 78/1, 119-39.

Weissenrieder, Annette and Robert B. Coote. 2015. The Interface of Orality and Writing: Speaking, Seeing, Writing in the Shaping of New Genres. Eugene: Wipf \& Stock. 